\title{
Lactarius megalopterus, a new angiocarpous species from a tropical rainforest in Central Africa, shows adaptations to endozoochorous spore dispersal
}

\author{
Ludwig Beenken ${ }^{1,2} \cdot$ Moses N. Sainge ${ }^{3,4}$ - Alexander Kocyan ${ }^{5}$ \\ Received: 22 December 2015 /Revised: 3 May 2016/Accepted: 13 May 2016 \\ (C) German Mycological Society and Springer-Verlag Berlin Heidelberg 2016
}

\begin{abstract}
A new sequestrate Lactarius species was found in a humid evergreen tropical rainforest dominated by Fabaceae of the subfamily Caesalpinioideae in Cameroon, Central Africa. It is described here as new to science and is named Lactarius megalopterus, referring to its spore ornamentation of extraordinarily high wings. Anatomical characters and molecular systematic analyses confirm its relationship to Lactarius subgenus Plinthogali. Phylogenetic analyses based on two nuclear DNA regions revealed its close relationship to Lactarius angiocarpus, which is also an angiocarpous species from Zambia in Africa. Molecular studies have shown that tuberlike, sequestrate sporocarps evolved independently in several lineages of Basidiomycota. The findings of sequestrate fungi in tropical rainforests raise questions regarding the evolutionary benefit of enclosing the spore-producing hymenium. The enclosure of spore-producing tissue has often been associated
\end{abstract}

Section Editor: Zhu-Liang Yang

Ludwig Beenken

ludwig.beenken@env.ethz.ch

1 ETH Zurich, Institute of Integrative Biology, Universitaetstrasse 16, 8092 Zurich, Switzerland

2 Present address: Swiss Federal Institute for Forest, Snow and Landscape Research WSL, Zürcherstrasse 111, 8903 Birmensdorf, Switzerland

3 Tropical Plant Exploration Group (TroPEG), P.O. Box 18, Mundemba, Ndian, South West Region, Cameroon

4 Department of Environmental and Occupational Studies, Faculty of Applied Science, Cape Peninsula University of Technology, Cape Town Campus, Keizersgracht, P.O. Box 652, Cape Town 8000, South Africa

5 Institute of Biochemistry and Biology, Biodiversity Research/ Systematic Botany, University of Potsdam, Maulbeerallee 2a, D-14469 Potsdam, Germany with the protection of the delicate hymenium against desiccation in arid habitats or against frost in cold habitats. However, these cannot be the selective factors in warm and humid areas like the tropics. This controversy is exemplarily studied and discussed in the family of Russulaceae, especially in the genus Lactarius. Characters shown by the angiocarpous sporocarp of the new Lactarius, such as thick-walled statismospores, an aromatic smell and mild taste, can be interpreted as adaptations to endozoochorous spore dispersal by mammals. Therefore, here we prefer the alternative hypothesis that sequestrate sporocarps are the result of adaptation to endozoochorous spore dispersal.

Keywords Russulaceae Lactarius subgenus Plinthogali . Mycophagy $\cdot$ Endozoochory syndrome $\cdot$ Cameroon

\section{Introduction}

The milk-cap genera Lactarius Pers. and Lactifluus (Pers.) Roussel show high diversity in tropical regions, especially in Africa, where about 100 species are identified up to now (Van Rooij et al. 2003; Douanla-Meli and Langer 2009; Van de Putte et al. 2009; Verbeken and Walleyn 2010; Maba et al. 2014) and even more species are to be expected (Verbeken and Buyck 2002). They are among the most important and diverse genera of ectomycorrhizal fungi in this region (Verbeken and Buyck 2002; Verbeken and Walleyn 2010). Thirteen Lactarius and Lactifluus species have been reported from Cameroon, and four of these (Lactarius desideratus Verbeken \& Stubbe, L. dewevrei Douanla-Meli, L. uapacae Verbeken \& Stubbe, L. undulatus Verbeken) have recently been described as new to science (Verbeken et al. 2008; Douanla-Meli and Langer 2009). Until now, only two sequestrate Lactarius species were known from sub-Saharan tropical Africa: the secotioid Lactarius dolichocaulis (Pegler) 
Verbeken \& Eberhardt and the angiocarpous L. angiocarpus Verbeken \& Eberhardt (Verbeken and Walleyn 2010). Both were collected in the relatively dry Zambezian miombo woodlands (Eberhardt and Verbeken 2004; Pegler 1982). In the present study, a third, new sequestrate Lactarius species is described from a very humid tropical rainforest in Southwest Cameroon.

Sequestrate sporocarps are well known from truffles and other Ascomycota, but have evolved fairly often in several clades within the Basidiomycota as well (e.g. Bruns et al. 1989; Læssøe and Hansen 2007; Wilson et al. 2011; Smith et al. 2015). Among Basidiomycota, sequestrate sporocarps have been detected in the family Russulaceae (e.g. Miller et al. 2001; Lebel and Tonkin 2007), especially in the genus Lactarius (e.g. Verbeken et al. 2014). Such an evolutionary transition to sequestrate sporocarps enclosing the delicate hymenium can be interpreted as a mechanism of protection against desiccation in arid habitats (e.g. Thiers 1984; Bruns et al. 1989) or against frost in cold areas (Trappe 1988; Maser et al. 2008). However, recent records of angiocarpous fungi from humid tropical rainforests contradict these climate-based explanations (e.g. Verbeken et al. 2014; Smith et al. 2015). Hence, in tropical regions and in humid temperate climates, other factors may trigger the evolution to angiocarpous sporocarps (e.g. Bougher and Lebel 2001; Trappe and Claridge 2005).

A special kind of sequestrate fungi are those that are adapted to mycophagous animals that feed from the sporocarps and transport the spores within their intestines. This endozoochorous spore dispersal (endozoochory) requires the evolution of several characters that attract feeding animals, and at the same time requires that fungi develop protective features against destructive digestion of the spores (Fogel and Trappe 1978; Johnson 1996; Maser et al. 2008). The angiocarpous sporocarp of the newly described Lactarius has such features and may be suited to endozoochorous spore dispersal.

To elucidate diagnostic characters of this new species, we conducted a detailed descriptive anatomical study along with a molecular systematic study of two nuclear DNA sequence regions to obtain phylogenetic information in a wider Lactarius context. We also reviewed the available literature on endozoochorous spore dispersal and examined established views on the evolution of this feature.

\section{Materials and methods}

\section{Morphological analysis}

The description of the macroscopic features is based on field observations of a fresh fruit body discovered during an expedition to Cameroon in 2002. The new species was collected only once at the type locality, and thus all data presented here are from the type specimen. Microscopic characters are based on dried material. Spores were described and drawn after treatment with Melzer's reagent. The measurements (without ornament) are based on 25 observed spores. Length, width, length/width ratio $(\mathrm{Q})$ and volume $(\mathrm{V})$ are given as minimum-mean-maximum values. The volumes are calculated using the formula of the rotational ellipsoid.

Basidia were stained with ammoniacal Congo red following brief aqueous potassium hydroxide $(\mathrm{KOH})$ preparation. Basidia lengths exclude sterigmata. Peridiopellis and subperidial and hymenophoral tramas were studied from radial hand sections in $2 \% \mathrm{KOH}$. In addition, cryosections were obtained from the dried basidiocarp and the adherent rhizomorph, which had been previously macerated in aqueous $\mathrm{KOH}$ and incubated in glycerol water. The sections, 30 $60 \mu \mathrm{m}$ thick, were stained with cotton blue/lactic acid. The terminology for peridiopellis (as pileipellis) structures and hymenial elements is according to Heilmann-Clausen et al. (1998) and Verbeken and Walleyn (2010). Scanning electron microscopy (SEM) images were obtained for air-dried material after sputtering with gold.

\section{Molecular analysis}

DNA was isolated from a small piece of gleba from the dried fruit body using the Dynabeads DNA DIRECT Universal kit (Dynal Biotech), according to the instructions for fungal tissue. The ITS1, 5.8S and ITS2 regions of the nuclear rDNA were amplified by polymerase chain reaction (PCR) using the primers ITS1F and ITS4B (Gardes and Bruns 1993). Cycle sequencing reactions were carried out with primers ITS1 and ITS4 (White et al. 1990) using the BigDye Terminator kit v3.1 (Applied Biosystems, Foster City, CA, USA). The LSU was amplified and sequenced using the primers LR0R and LR3 (Vilgalys and Hester 1990). Processed cycle sequencing products were run on an ABI PRISM 3100-Avant Genetic Analyzer capillary sequencer (Applied Biosystems).

Sequences were edited with Sequencher 4.10 software (Gene Codes, Ann Arbor, MI, USA) and deposited at GenBank. The ITS and LSU sequences were compared with accessions deposited at GenBank by applying the Basic Local Alignment Search Tool (BLAST) with the nucleotide search option (blastn) to classify the Lactarius species. Subsequently, ITS and LSU Lactarius sequences were obtained from GenBank in order to compile independent alignments to test for the phylogenetic position of the new Lactarius species (for GenBank accession numbers see Fig. 1). Alignments were performed using MUSCLE 3.8.31 (Edgar 2004). All of the ingroup taxa belong to Lactarius subg. Plinthogali. The nonPlinthogali L. hispidulus was used as outgroup (derived from Verbeken et al. 2014 and Stubbe and Verbeken 2012). Ambiguously aligned regions were delimited and excluded from phylogenetic analyses with Gblocks version 0.91b (Castresana 2000). 


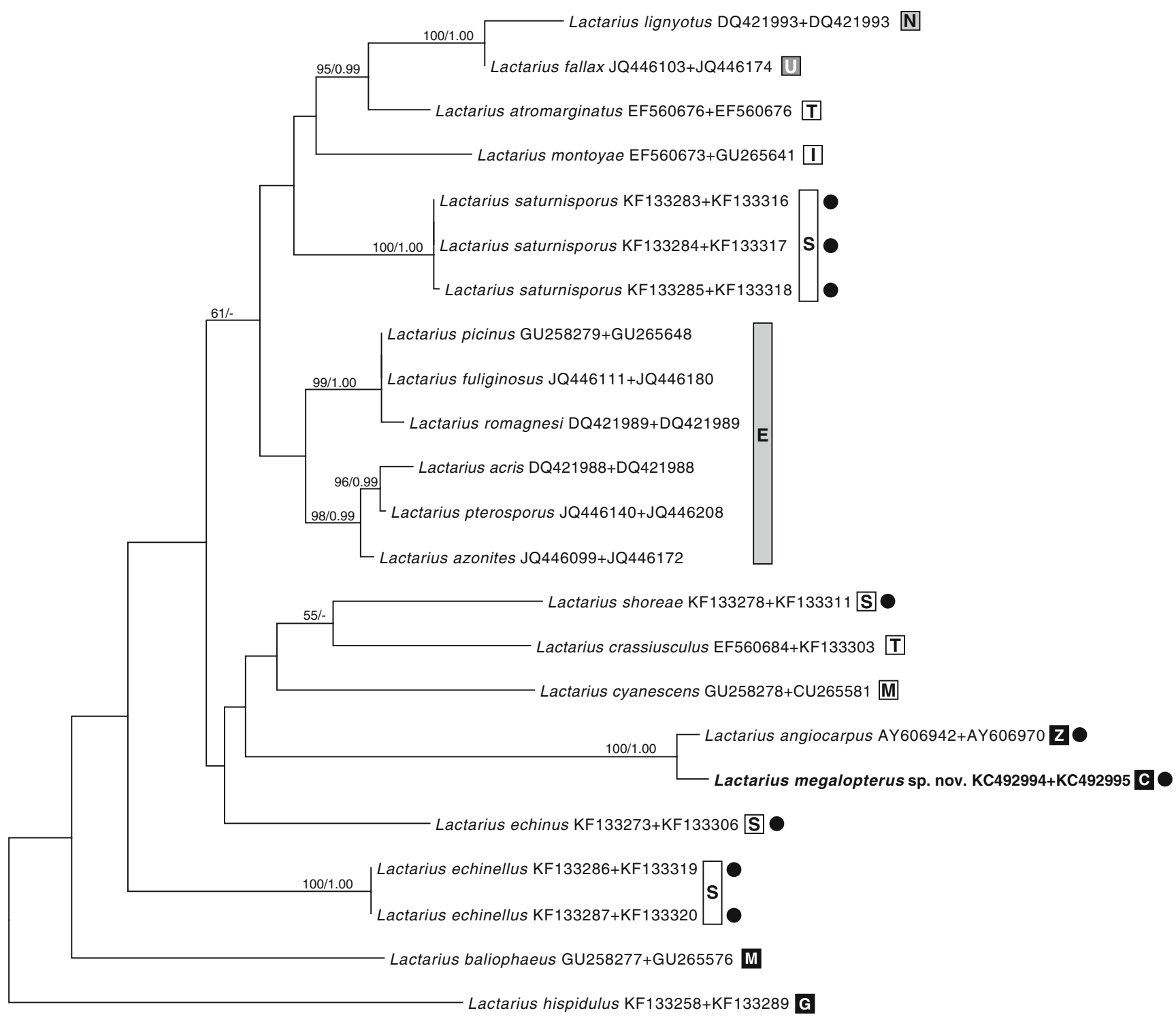

Fig. 1 Maximum-likelihood tree of Lactarius subg. Plinthogali obtained from the combined datasets of ITS + LSU. The phylogenetic position of the newly described Lactarius megalopterus is indicated in bold letters. Angiocarpous species are identified by black dots. Bars denote geographic origin of samples: black, Africa $(Z=Z a m b i a$, $\mathrm{C}=$ Cameroon, $\mathrm{G}=$ Guiana, $\mathrm{M}=$ Malawi); white, Asia $(\mathrm{S}=$ Sri Lanka,

These two datasets resulted in the same tree topology; hence, they were combined and analyzed with maximum likelihood methods implemented in RAxML version 7.2.8 (Stamatakis 2006). Analysis was performed assuming a general time-reversible (GTR) model of nucleotide substitution, estimating a discrete gamma distribution (GTRGAMMA option in RAxML) with partitions according to the sub-matrices, allowing for multiple models of substitution. One thousand runs with distinct starting trees were completed for each dataset using the rapid bootstrap (BS) algorithm of RAxML (Stamatakis et al. 2008). Bayesian analysis was
$\mathrm{M}=$ Malaysia, $\mathrm{T}=$ Thailand, $\mathrm{I}=$ India $)$; light grey, Europe $(\mathrm{N}=$ North Europe, $\mathrm{E}=$ Central Europe); dark grey, North America ( $\mathrm{U}=\mathrm{USA}$ ). Numbers above branches indicate RAxML bootstrap support $>50 \%$ / Bayesian posterior probabilities $>0.90$. With the exception of L. megalopterus, all sequences were obtained from GenBank. GenBank accession numbers of ITS + LSU are given behind the species names

performed with MrBayes 3.2.1 (Huelsenbeck and Ronquist 2001; Ronquist and Huelsenbeck 2005) on the same dataset as the maximum likelihood analysis. Independent GTR models with gamma distribution approximated by four categories were implemented for all data partitions, with four chains and ten million generations, sampling every 100th tree. Post-burn-in trees were collected and the summarizations calculated only when the standard deviation of split frequencies reached levels below 0.01. Posterior probability (PP) values equal to or greater than 0.95 were considered significant. The phylogenetic ML tree was visualized 
and rooted using the Dendroscope program (Huson et al. 2007).

\section{Results}

\section{Molecular phylogeny}

ITS1-5.8S-ITS2 and LSU of Lactarius megalopterus had lengths of $661 \mathrm{bp}$ and $581 \mathrm{bp}$, respectively. When compared with sequences deposited at GenBank, both sequences showed the highest similarity to the sequences of L. angiocarpus of $L$. subgenus Plinthogali (blastn: ITS [AY606942] $97 \%$ identity, LSU [AY606970] $99 \%$ identity). The computed phylogeny was therefore restricted to species of $L$. subg. Plinthogali. Both types of analyses (RaxML, MrBayes) resulted in the same tree topology (Fig. 1). The two sequestrate species from Africa, L. megalopterus and L. angiocarpus, paired in a maximally supported clade (100\% BS, 1.00 PP). The four African species and the seven European, one North American and eight Asian species, respectively, appeared as polyphyletic geographic groups. The six angiocarpous Lactarius species appeared as polyphyletic.

\section{Taxonomy}

Lactarius megalopterus Beenken \& Sainge, sp. nov. MycoBank MB 803213; Figs. 2, 3, 4 and 5

Etymology: The name megalopterus refers to the highly

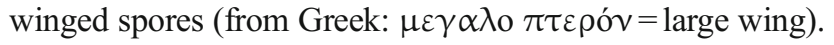

Macroscopic features-Basidiocarp (Fig. 2) $55 \times 45 \times 40 \mathrm{~mm}$, tuberous, consisting of subglobose to irregular parts, epigeous. Peridial surface smooth, dry, buff-yellow to orange with pinkish tinge after bruising, paler at base. Gleba pale pinkish-brown, lacunose, with 0.5-1(2) mm wide labyrinthine locules. Stipe and columella absent. Rhizomorphs at base of basidiocarp, up to $0.5 \mathrm{~mm}$ thick. Smell aromatic, rubber-like, with fruity components. Taste mild. Latex abundant, close to the peridia, sparse or absent in the gleba, white, pale pink when dried, mild.
Microscopic features - Hymenium: Basidiospores (Figs. 3c and 4) globose to subglobose $(\mathrm{Q}=1-1.07-1.18), 8.5-9.6$ $11 \times 8-9.0-10.5 \mu \mathrm{m}, \mathrm{V}=285-411.2-632 \mu \mathrm{m}^{3}$, symmetric and orthotropic; spore wall $0.75-1 \mu \mathrm{m}$ thick; ornamentation amyloid, highly winged, ridges up to 3.5(4) $\mu \mathrm{m}$ high, often encompassing half or more of the spore circumference, rarely branched but never reticulate, isolated shorter ridges, spines and warts between the main ridges; hilar appendix 2-2.5 $\times 1.5-2 \mu \mathrm{m}$; suprahilar plage absent. Basidia (Fig. 3b) $45-60 \times 12-16 \mu \mathrm{m}$, occasionally up to $80 \times 25 \mu \mathrm{m}$, 4-spored, clavate, thin-walled; sterigmata 5-6(8) $\mu \mathrm{m}$ long. True cystidia and pseudocystidia (gloeocystidia) absent. Sterile elements not found. Hymenophoral trama 30-100 $\mu \mathrm{m}$ wide, composed of net-like, loosely arranged hyphae, 3-6 $\mu \mathrm{m}$ in diam., hyphal walls $0.3 \mu \mathrm{m}$ thick, close to the hymenium (subhymenium), with spherocytes arranged candelabra-like (Fig. 5b), not gelatinized; lactiferous hyphae absent or very rare. Peridiopellis (Figs. 3a and 5a) palisade-like, 30-70 $\mu$ m thick, twolayered; (i) upper layer pseudoparenchymatous, cells \pm isodiametric, (5)10-30(40) in diam., walls gelatinized, $0.5-2 \mu \mathrm{m}$ thick; bearing short, septate ascending hyphae $(15-50 \times 4-7 \mu \mathrm{m})$ sparsely scattered over the surface, walls $0.3-0.5 \mu \mathrm{m}$ thick; (ii) underlying hyphae interwoven, distinctly gelatinized, 3-6(7) $\mu \mathrm{m}$ in diam. Subperidial trama 200-300 $\mu \mathrm{m}$ thick, composed of subparallel, colorless, hyaline hyphae 3-6(7) $\mu \mathrm{m}$ in diam., hyphal walls $0.3-0.5 \mu \mathrm{m}$ thick; lactiferous hyphae abundant, $5-20 \mu \mathrm{m}$ in diam., walls $0.5-1(1.5) \mu \mathrm{m}$ thick, gelatinization weak to absent.

Rhizomorphs (Fig. 3d) two-layered; centrally composed of four distinct types of hyphae: (i) parallel colorless, hyaline hyphae 3-6 $\mu \mathrm{m}$ in diam., hyphal walls $0.3-0.5 \mu \mathrm{m}$ thick; (ii) lactiferous hyphae with granulose content, $5-10 \mu \mathrm{m}$ in diam., walls $0.5-$ 1(1.5) $\mu \mathrm{m}$ thick, septa in long distances; (iii) vessel-like hyphae similar to lacitfers but without content, 5-20 $\mu \mathrm{m}$ in diam; (iv) hyphae with numerous arched septa, distance between septa $10-20 \mu \mathrm{m}, 10-15 \mu \mathrm{m}$ in diam., walls $1-1.5 \mu \mathrm{m}$ thick; outer layer similar to the peridiopellis, $30-40 \mu \mathrm{m}$ thick, cells up to $20 \times 30 \mu \mathrm{m}$, walls gelatinized, $0.5-2 \mu \mathrm{m}$ thick, short ascending hyphae not observed. Clamp connections in all hyphae absent.

Type: CAmeroon, Southwest Region, Ndian Division, Diongo Community Forest, peripheral zone of the Onge Forest Reserve, SE of Bamusso, close to Diongo village,
Fig. 2 Lactarius megalopterus (holotype). Basidiocarp ca. $55 \times 45 \times 40 \mathrm{~mm}$ (b in section), with feeding mark on the bottom right
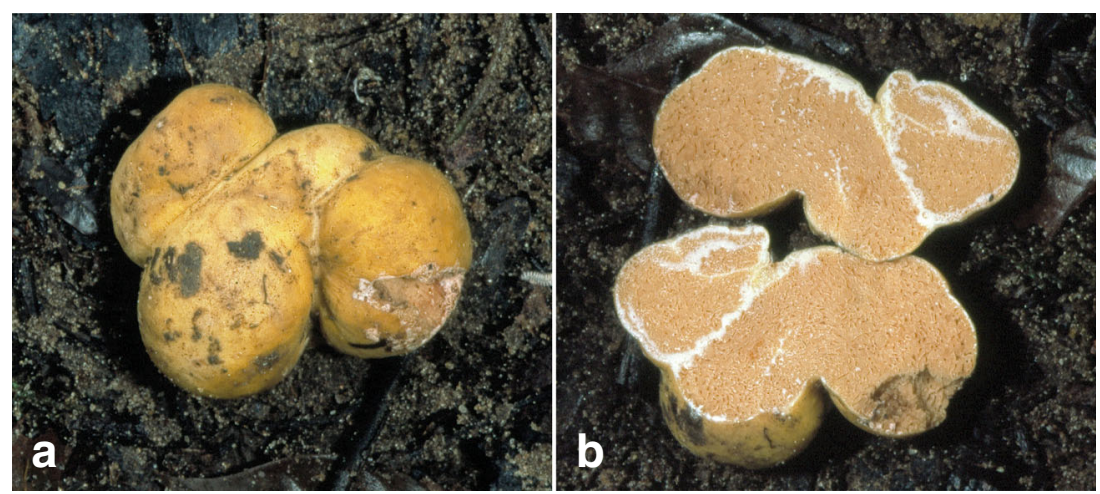

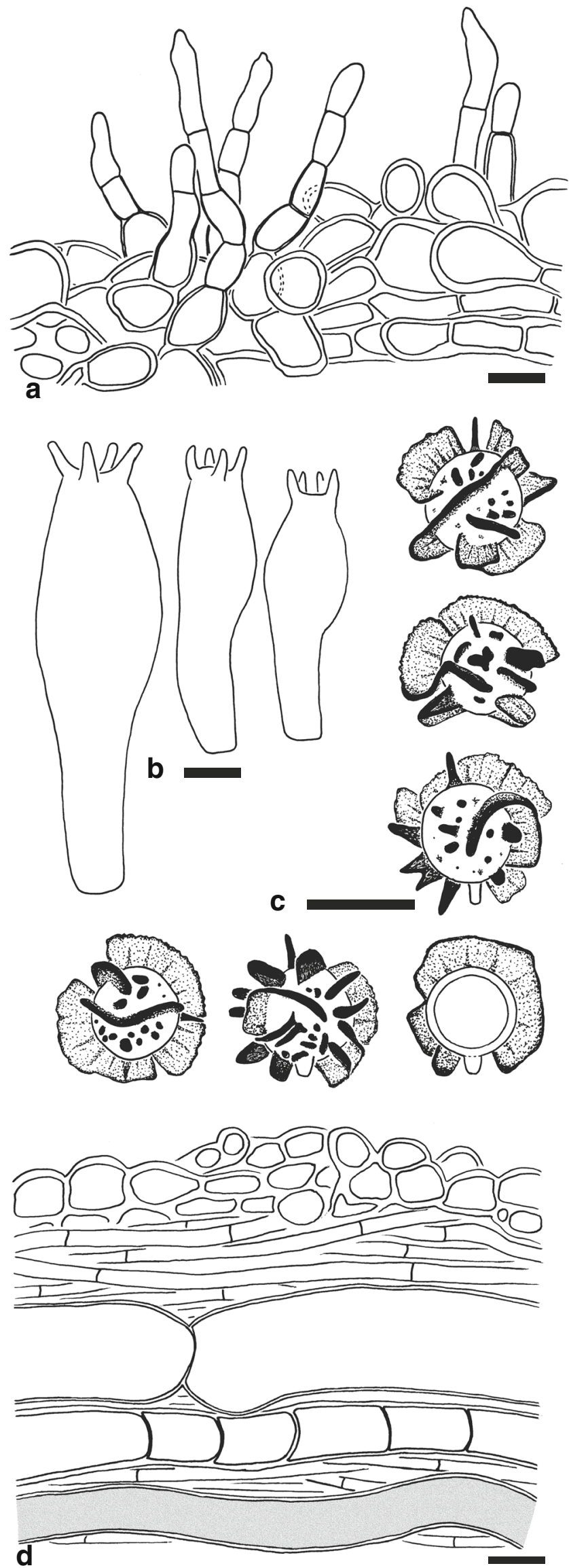

4 Fig. 3 Lactarius megalopterus (holotype). a Section through the outer peridiopellis with septate ascending hyphae. b Basidia, on the left an extremely large one. c Basidiospores (on the bottom right, optical section showing the thick spore wall). d Longitudinal section through a rhizomorph with cellular outer surface and with vessel-like hypha, ladderlike hypha and lactifer in the inner part (top to bottom). Scale bars $=10 \mu \mathrm{m}$

$4^{\circ} 25^{\prime}$ N, $8^{\circ} 57^{\prime}$ E, alt c. 200 m, 17 Oct. 2002, leg. M. N. Sainge and L. Beenken, no. K02/79 (holotype in YA, isotype in M). GenBank accession numbers: ITS1-5.8S-ITS2 sequence KC492994; LSU partial sequence KC492995.

Habitat - Lactarius megalopterus was fruiting above ground in the litter of a dense rainforest. The Onge area at the western side of Mount Cameroon is one of the most humid regions in Africa (6-7 $\mathrm{m}$ of rain per year) with major rainfall from June to October and a drier period from November to May (Cable and Cheek 1998). Lactarius megalopterus was collected in October at the end of the rainy season. The area is part of the Lower Guinean phytochorion and one of the plant species-richest areas in western Africa, with a high rate of endemism (Beentje et al. 1994; Cable and Cheek 1998; Mutke et al. 2001). The type locality of L. megalopterus is a humid evergreen rainforest dominated mainly by ectomycorrhiza-forming trees such as the genera Anthonotha, Gilbertiodendron, Microberlinia, Tetraberlinia (Fabaceae of subfamily Caesalpinioideae) and Uapaca (Phyllanthaceae) (Smith and Read 2008). Thus, species of these genera may be ectomycorrhizal partners of L. megalopterus, although it was not possible to assign the

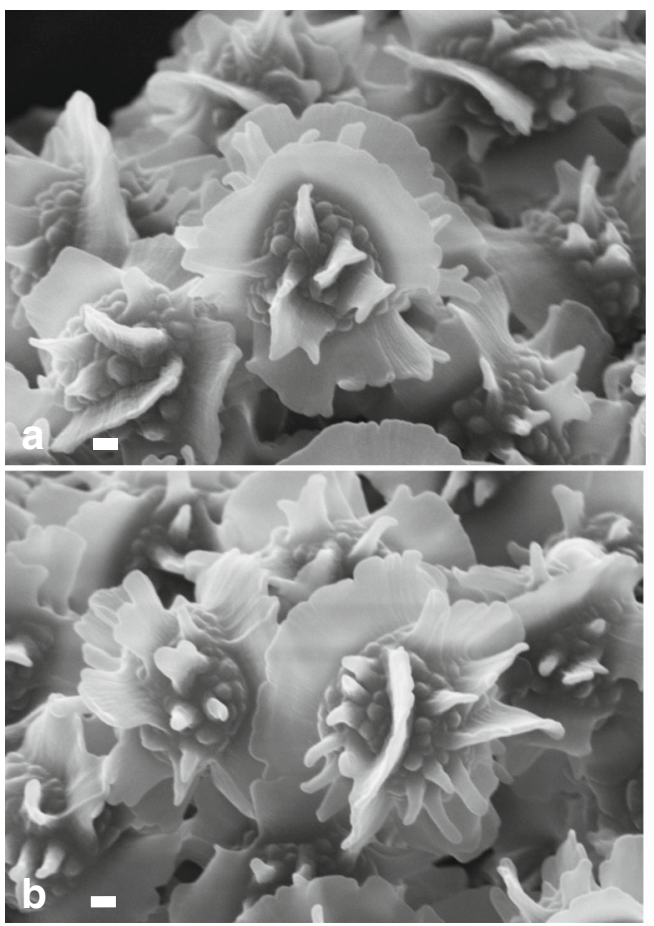

Fig. 4 Lactarius megalopterus (holotype). Basidiospores (SEM). Scale bars $=1 \mu \mathrm{m}$ 


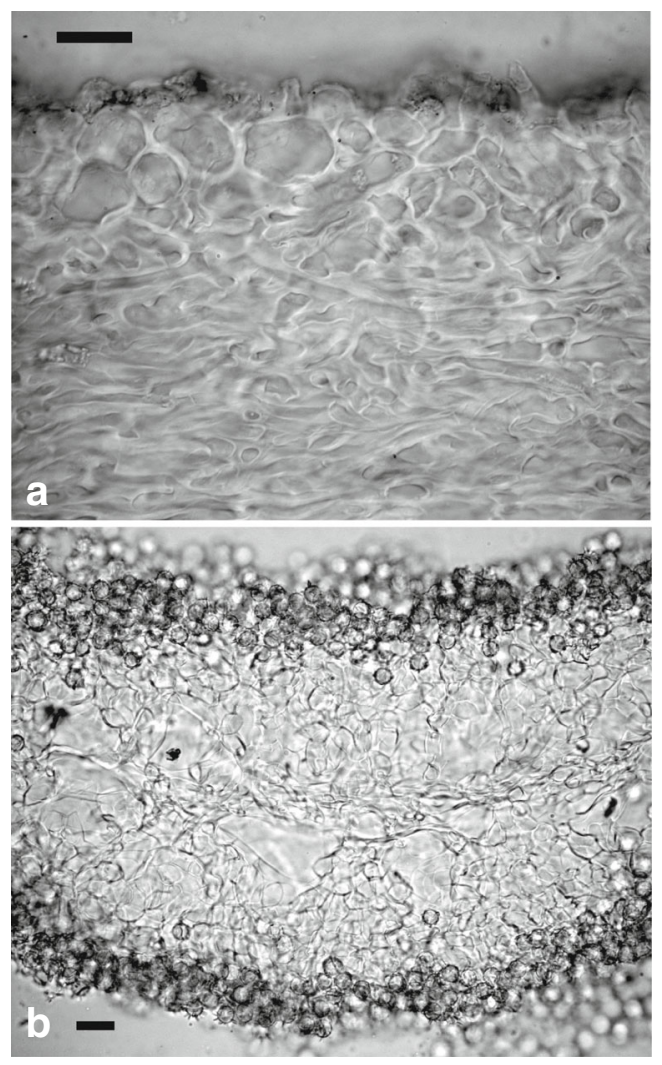

Fig. 5 Lactarius megalopterus (holotype). a Section through the peridiopellis. b Section through gleba. Scale bars $=20 \mu \mathrm{m}$

fungus to a specific tree. Located close to the village of Diongo, the forest suffers from human impact of logging and hunting.

\section{Discussion}

\section{Taxonomy and morphology}

Molecular phylogenetic studies have shown that Arcangeliella, Gastrolactarius and Zelleromyces represent artificial genera for sequestrate Lactarius species, and may be better subsumed in the amplified genus Lactarius (e.g. Nuytinck et al. 2003; Verbeken et al. 2014; Kirk 2015; Pierotti 2015). To date, sequestrate forms are not reported from the genus Lactifluus (Verbeken et al. 2014). As the sequestrate life habit evolved several times independently within various subgenera of Lactarius, this character is the result of convergent evolution (Miller et al. 2001; Peter et al. 2001; Desjardin 2003; Nuytinck et al. 2003; Eberhardt and Verbeken 2004; Verbeken et al. 2014). The newly described Lactarius megalopterus supports this presumption. According to our molecular data, L. megalopterus is closely related to L. angiocarpus from Zambia, an also angiocarpous species belonging to Lactarius subg. Plinthogali (Fig. 1; Eberhardt and Verbeken 2004; Verbeken et al. 2014). Our tree topology matches well with the corresponding subclades in the more extensive analyses of Verbeken et al. (2014) and with the analysis of Stubbe and Verbeken (2012), respectively.

The placement of L. megalopterus within $L$. subg. Plinthogali is also well supported by morphological characters. A spore ornamentation composed of highly winged ridges is characteristic of this subgenus. Also, the pileipellis is often palisade-shaped (Heilmann-Clausen et al. 1998; Verbeken 2000; Verbeken and Walleyn 2010; Stubbe and Verbeken 2012). White latex, turning reddish when exposed to air, is characteristic of many species of $L$. subg. Plinthogali as well (De Bernadi et al. 1992; Sterner 1995; Verbeken 2000).

The sister species of L. megalopterus is L. angiocarpus. The new species is well differentiated from $L$. angiocarpus in various morphological and anatomical characters. Although both species have subglobose to irregularly shaped fruit bodies, without stipe and columella, the sporocarp of L. angiocarpus is smaller, and its peridia and gleba are both light-cream, without yellow, pinkish or brown colors. Laticifers and pseudocystidia occur in the hymenophoral trama of $L$. angiocarpus, and thus the latex is abundant in the whole gleba, not only near the peridia, and remains white. The spores of $L$. angiocarpus bear shorter wings, forming an incomplete net. Its peridiopellis is a trichoderm and not palisade-like. These pronounced morphological differences split L. megalopterus well from L. angiocarpus.

The secotioid L. dolichocaulis from Zambia, thus far not sequenced, differs from L. megalopterus in its rather agaricoid habit, with cap and stipe and reticulate spore ornamentation (Pegler 1982; Verbeken 2000; Verbeken and Walleyn 2010). L. dolichocaulis is only similar to L. megalopterus in the gleba-like hymenium without true cystidia and pseudocystidia (Verbeken 2000; Verbeken and Walleyn 2010). It is worth mentioning that all known sequestrate Lactarius species from tropical Africa belong to L. subg. Plinthogali (Eberhardt and Verbeken 2004; Verbeken and Walleyn 2010).

Additional angiocarpous representatives of $L$. subg. Plinthogali from tropical Sri Lanka are reported to be associated with Dipterocarpaceae (Verbeken et al. 2014). Of these, L. saturnisporus Verbeken \& Stubbe and L. shoreae Stubbe \& Verbeken have like L. megalopterus highly winged spores, whereas L. echinellus Verbeken \& Stubbe and L. echinus Stubbe \& Verbeken differ from $L$. megalopterus by echinate spore ornamentation. Arcangeliella beccarii (Petri) Zeller \& C.W. Dodge and A. malaiensis Corner \& Hawker from Malaysia (Corner and Hawker 1953) and Australia (Beaton et al. 1984, as Zelleromyces malaiensis [Corner \& Hawker] A.H. Sm.), respectively, are also angiocarpous lactarioid species that have globose spores ornamented with very high ridges forming incomplete nets. They may also belong to $L$. subg. Plinthogali, but a recombination to Lactarius should not be done without having studied their type specimens. 
The rhizomorph of L. megalopterus has a typical anatomy, which is otherwise known only from the rhizomorphs of Lactarius, Lactifluus and Russula (Russulaceae) (Beenken 2001a, b; 2004; russoloid rhizomorphs sensu Agerer 1999): it is divided into an outer layer and an inner part containing lactifers, vessel-like hyphae and densely septate hyphae with arched septa (ladder-like hyphae sensu Agerer 1999). Lactiferous hyphae are common in the rhizomorphs of Lactarius but are absent in Russula species and Lactifluus piperatus (Beenken 2001a, b, 2004).

\section{The endozoochory syndrome}

Lactarius megalopterus shows all morphological features characteristic of truffle-like fungi with spore dispersal by mycophagous mammals via endozoochory. The characteristics of this endozoochorous spore dispersal syndrome include sporocarps with a peridium enclosing a fleshy, chambered gleba bearing the hymenium, thick-walled statismospores, and a smell attracting animals (Fogel and Trappe 1978; Trappe and Cázares 1990; Johnson 1996; Claridge 2002; Trappe and Claridge 2005). Therefore, we hypothesize that L. megalopterus has an endozoochorous dispersal mode, and we justify this assumption in detail below.

The first hint was that the field-collected sporocarp showed parallel tooth-marks, which are typical indications of the feeding habits of small rodents (Fig. 2). Hastings and Mottram (1916) described and illustrated similar tooth-marks of rodents on European mushrooms. Furthermore, an aromatic smell of L. megalopterus was detected in the field that did not resemble any smell we know from lamellate Lactarius species in Africa or Europa. This special smell may attract mammals. The spore morphology of L. megalopterus is the main indication of dispersal by means other than air. In contrast to air-dispersed, thin-walled and asymmetric ballistospores, which are known from lamellate Russulaceae (e.g. Nilsson 1983, HeilmannClausen et al. 1998), the basidiospores of L. megalopterus are radially symmetrical, orthotropic and without suprahilar plage. Thus, they show the characters of so-called statismospores, having lost their features of ballistic spore dispersion (Pegler and Young 1979; Miller 1988; Miller and Miller 1988). In addition, the walls of these spores are much thicker $(0.75-1 \mu \mathrm{m})$ than those of airborne ballistospores of Lactarius spp. $(<0.5 \mu \mathrm{m}$, authors' own unpublished observations, microphotographs in Nilsson 1983) reported for many sequestrate genera or species of several other fungal families with references to animal mycophagy (e.g. Castellano et al. 1989). These thick spore walls, and likely the unusual high ornaments, may protect the spores against digestion during their intestinal passage (Trappe and Claridge 2005). Lescourret and Génard (1986) showed that the digestive enzymes of small mammals affect the spore surfaces. Thus, germination of spores adapted to endozoochory may be promoted even after passing through a mammal's gut (Kotter and Farentinos 1984; Cork and Kenagy 1989; Claridge et al. 1992; Johnson 1996; Reddell et al. 1997; Colgan and Claridge 2002; Trappe and Claridge 2005). In many agaricoid Lactarius species, the sporocarp exudes an acrid-tasting latex as a mechanism for fending off several predators, especially from the lamellae with the hymenium (Camazine and Lupo 1984; Sterner 1995; Stadler and Sterner 1998). However, the pungent latex ingredients can be an antifeedant against mammals (Camazine et al. 1983). In the case of endozoochorously dispersed Lactarius species, such an antifeedant would be counterproductive. Hence, this could explain the milder taste of the latex of L. megalopterus and L. angiocarpus, and the reduction of lactiferous hyphae as well as the lack of cystidia in the gleba of L. megalopterus. Various species of the L. subg. Plinthogali are acrid and toxic, but there are also many species with a sweet taste. Some of these are edible for humans (Heilmann-Clausen et al. 1998, Karhula et al. 1998; Verbeken 2000). However, the edibility of L. megalopterus for humans is unknown, as the natives of Diongo village and its environs do not consume this species.

In conclusion, we think that there is a strong indication of endozoochoric spore dispersal of L. megalopterus provided by the indirect morphological evidence explained above, even though we were not able to prove our hypothesis through direct observation of animals feeding on L. megalopterus or the spores passing through the digestive tract of an animal in the field.

The habitat of L. megalopterus supports the hypothesis that its angiocarpous sporocarp is not an adaptation to extreme climate conditions, as the specimen was found in one of the wettest regions of tropical Africa at the end of the rainy season. The type locality lies in the western foothills of Mount Cameroon, a hilly area belonging to a glacial refuge that was continuously covered by rainforest in the past, even during the dry periods of the Quaternary (Maley 1996; Sosef 1996; Maley and Brenac 1998). Therefore, the sequestrate habit of L. megalopterus has obviously evolved under wet conditions and not in a dry environment. However, L. megalopterus is not an isolated case of a sequestrate fungus from humid tropical Africa (Dring and Pegler 1978; Verbeken and Walleyn 2003). The two first authors (L.B., M.N.S.) have found two other angiocarpous fungi in the Cameroon rainforests showing similar adaptations to endozoochorous spore dispersal (Gelopellis rufus Dring [Phallaceae], Octaviana sp. [Boletaceae]; unpublished data). In addition, the sporocarps of the closely related $L$. angiocarpus and of the secotioid L. doliocaulis were collected from the miombo woodlands in Zambia in December at the peak of the rainy season (Eberhardt and Verbeken 2004; Pegler 1982; http://en. climate-data.org). Outside tropical Africa, angiocarpous Lactarius species occur in the tropical rainforests of Southeast Asia (Verbeken et al. 2014). Smith et al. (2015) 
described three angiocarpous taxa of Boletaceae (Boletales) from tropical South America, which were collected during rainy seasons in a primary rainforest dominated by ectomycorrhizal tree species in Guyana. Sequestrate habits have been found to occur even in moderate, humid to wet climates of Europe, North America, Australia and New Zealand (e.g. Jülich 1984; Bougher and Lebel 2001; Trappe and Claridge 2005). Lastly, Reddell et al. (1997) detected spores of several ectomycorrhizal fungi in scats of 17 mammal species in tropical forests of northeastern Australia, including basidiospores of sequestrate Russulaceae.

These observations of sequestrate fungi from wet tropical and temperate areas contradict the general assumption that the sequestrate habit is an adaptation of fungal sporocarps to dry conditions as protection of the hymenium against desiccation or against other climatic stress such as heat or cold (e.g. Thiers 1984; Trappe 1988; Bruns et al. 1989; Maser et al. 2008). Hence, the adaption to endozoochorous spore dissemination is a more plausible explanation for the evolution of sequestrate fungi, particularly in humid forest habitats.

Regardless of temperature and humidity, endozoochory may be a more effective strategy than aerial transport for spore dissemination in closedcanopy forests with no winds close to the ground (Trappe and Claridge 2005). This type of dispersal is particularly important for ectomycorrhizal fungi (Johnson 1996; Frank et al. 2006, 2009; Maser et al. 2008; Schickmann et al. 2012).

Our hypothesis that endozoochorous spore dissemination plays a major role in the evolution of sequestrate fungi is supported by the fact that even some agaricoid species show an affinity for endozoochorous spore dispersal (CastilloGuevara et al. 2011). Such adaptation is a necessary precondition for successful spore dissemination after an enclosed hymenium has evolved.

Acknowledgments We thank Thassilo Franke (Munich, Germany) for organizing and accompanying the first two authors on the field trip in Cameroon. We are grateful for the hospitality and field assistance of the people of Diongo village. Our gratitude also goes to Eva Facher (University of Munich, Germany) for assisting with the SEM and to Jasmin Joshi (University of Potsdam) for valuable comments on the manuscript. The first author sincerely thanks Annemike Verbeken (Gent, Belgium) for the gift of her book Monograph of Lactarius in tropical Africa.

\section{References}

Agerer R (1999) Never change a functionally successful principle: the evolution of Boletales s.l. (Hymenomycetes, Basidiomycota) as seen from below-ground features. Sendtnera 6:5-91

Beaton G, Pegler DN, Young TWK (1984) Gasteroid Basidiomycota of Victoria state, Australia, 2. Russulales. Kew Bull 39:669-698
Beenken L (2001a) Russula aeruginea Lindbl. ex Fr. + Betula pendula Roth. Descr Ectomycorrhizae 5:107-113

Beenken L (2001b) Russula densifolia Sécr. ex Gil. + Fagus sylvatica L. Descr Ectomycorrhizae 5:147-155

Beenken L (2004) Die Gattung Russula, Untersuchungen zu ihrer Systematik anhand von Ektomykorrhizen. Dissertation, LudwigMaximilians-Universität, Munich, Germany. http://edoc.ub.unimuenchen.de/archive/00003175/

Beentje HJ, Adams B, Davies SD (1994) Regional overview: Africa. In: Davies SD, Heywood VH, Hamilton AC (eds) Centres of plant diversity, vol 1. WWF and IUCN, Europe, pp 101-148

Bougher NL, Lebel T (2001) Sequestrate (truffle-like) fungi of Australia and New Zealand. Aust Syst Bot 14:439-484

Bruns TD, Fogel R, White TJ, Palmer JT (1989) Accelerated evolution of a false-truffle from a mushroom ancestor. Nature 339:140-142

Cable S, Cheek M (1998) The plants of Mount Cameroon, a conservation checklist. Royal Botanic Gardens, Kew

Camazine S, Lupo AT (1984) Labile toxic compounds of the Lactarii: the role of the laticiferous hyphae as storage depot for precursors of pungent dialdehydes. Mycologia 76:355-358

Camazine SM, Resch JF, Eisner T, Meinwald J (1983) Mushroom chemical defense: pungent sequiterpenoid dialdehyde antifeedant to opossum. J Chem Ecol 9:1439-1447

Castellano MA, Trappe JM, Maser Z, Maser C (1989) Key to spores of the genera of hypogeous fungi of north temperate forests with special reference to animal mycophagy. Mad River Press, Eureka

Castillo-Guevara C, Sierra J, Galindo-Flores G, Cuautle M, Lara C (2011) Gut passage of epigeous ectomycorrhizal fungi by two opportunistic mycophagous rodents. Curr Zool 57:293-299

Castresana J (2000) Selection of conserved blocks from multiple alignments for their use in phylogenetic analysis. Mol Biol Evol 17:540 552

Claridge AW (2002) Ecological role of hypogeous ectomycorrhizal fungi in Australian forests and woodlands. Plant Soil 244:291-305

Claridge AW, Tanton MT, Seebeck JH, Cork SJ, Cunningham RB (1992) Establishment of ectomycorrhizae on the roots of two species of Eucalyptus from fungal spores contained in the faces of the longnosed potoroo (Potorous tridactylus). Aust J Ecol 17:207-217

Colgan W, Claridge AW (2002) Mycorrhizal effectiveness of Rhizopogon spores recovered from faecal pellets of small forest-dwelling mammals. Mycol Res 106:314-320

Cork SJ, Kenagy GJ (1989) Nutritional value of hypogeous fungus for a forest-dwelling ground squirrel. Ecology 70:577-586

Corner EJH, Hawker LE (1953) Hypogeous fungi from Malya. Trans Br Mycol Soc 36:125-137

De Bernadi M, Vidari G, Vita Finzi P, Fronza G (1992) The chemistry of Lactarius fuliginosus and Lactarius picinus. Tetrahedron 48:73317344

Desjardin DE (2003) A unique ballistitosporic hypogeous sequestrate Lactarius from California. Mycologia 95:148-155

Douanla-Meli C, Langer E (2009) Fungi of Cameroon III. Two new Russulales species (Basidiomycota). Nova Hedwigia 88:491-502

Dring DM, Pegler DN (1978) New and noteworthy gasteroid relatives of the Agaricales from tropical Africa. Kew Bull 32:563-569

Eberhardt U, Verbeken A (2004) Sequestrate Lactarius species from tropical Africa: L. angiocarpus sp. nov. and L. dolichocaulis comb. nov. Mycol Res 108:1042-1052

Edgar RC (2004) MUSCLE: multiple sequence alignment with high accuracy and high throughput. Nucleic Acids Res 32:1792-1797

Fogel R, Trappe JM (1978) Fungus consumption (mycophagy) by small animals. Northwest Sci 52:1-31

Frank JL, Barry S, Southworth D (2006) Mammal mycophagy and dispersal of mycorrhizal inoculum in Oregon white oak wood- lands. Northwest Sci 80:264-273

Frank JL, Anglin S, Carrington EM, Taylor DS, Viratos B, Southworth D (2009) Rodent dispersal of fungal spores promotes seedling 
establishment away from mycorrhizal networks on Quercus garryana. Botany 87:821-829

Gardes MT, Bruns TD (1993) ITS primers with enhanced specificity for basidiomycetes, application to the identification of mycorrhizae and rusts. Mol Ecol 2:113-118

Hastings S, Mottram JC (1916) Observations upon the edibility of fungi for rodents. Trans Br Mycol Soc 5:364-378, 12 figs

Heilmann-Clausen J, Verbeken A, Vesterholt J (1998) The genus Lactarius. Fungi of Northern Europe Vol. 2, Svamperyk, Mundelstrup

Huelsenbeck JP, Ronquist F (2001) MrBayes: Bayesian inference of phylogenetic trees. Bioinformatics 17:754-755

Huson DH, Richter DC, Rausch C, Dezulian T, Franz M, Rupp R (2007) Dendroscope - an interactive viewer for large phylogenetic trees. BMC Bioinf 8:460

Johnson CN (1996) Interactions between mammals and ectomycorrhizal fungi. Trends Ecol Evol 11:503-507

Jülich W (1984) Die Nichtblätterpilze, Gallertpilze und Bauchpilze. In: Gams H (ed) Kleine Kryptogamenflora Band IIb/1. Gustav Fischer Verlag, Stuttgart

Karhula P, Härkönen M, Saarimäki T, Verbeken A, Mwasumbi L (1998) Tanzanien mushrooms and their use 6 Lactarius. Karstenia 38:4968

Kirk PM (2015) Nomenclatural novelties. Index Fungorum 278:1

Kotter MM, Farentinos RC (1984) Formation of ponderosa pine ectomycorrhizae after inoculation with faeces of tassel-eared squirrels. Mycologia 76:758-760

Læssøe T, Hansen K (2007) Truffle trouble: what happened to the Tuberales? Mycol Res 111:1075-1099

Lebel T, Tonkin JE (2007) Australasian species of Macowanites are sequestrate species of Russula (Russulaceae, Basidiomycota). Aust Syst Bot 20:355-381

Lescourret F, Génard M (1986) Dissémination de spores de champignons par les petits mammiféres. Mammalia 50:278-280

Maba DL, Guelly AK, Yourou NS, De Kesel A, Verbeken A, Agerer R (2014) The genus Lactarius s. str. (Basidiomycota, Russulales) in Togo (west Africa): phylogeny and a new species described. IMA Fungus 5:39-49

Maley J (1996) The African rain forest: main characteristics of changes in vegetation and climate from the upper Cretaceous to the Quaternary. Proc R Soc Edinb Biol 104:31-73

Maley J, Brenac P (1998) Vegetation dynamics, palaeoenvironments and climatic changes in the forests of western Cameroon during the last 28,000 years B.P. Rev Paleobot Palynol 99:157-187

Maser C, Claridge AW, Trappe JM (2008) Trees, truffles, and beasts: how forests function. Rutgers University Press, New Brunswick

Miller SL (1988) A systematic evaluation of basidiospore symmetry and tegumentation in hypogeous and gasteroid Russulales. Can J Bot 66: 2561-2573

Miller SL, Miller OK (1988) Spore release in hypogeous, gastreoid and agaricoid Russulales. Trans Br Mycol Soc 90:513-526

Miller SL, McClean TM, Walker JF, Buyck B (2001) A molecular phylogeny of the Russulales including agaricoid, gasteroid and pleurotoid taxa. Mycologia 93:344-354

Mutke J, Kier G, Braun G, Schulz C, Barthlott W (2001) Patterns of African vascular plant diversity - a GIS based analysis. Syst Geogr Plants 71:1125-1136

Nilsson S (1983) Atlas of airborne fungal spores in Europe. Springer, Berlin

Nuytinck J, Verbeken A, Delarue S, Walleyn R (2003) Systematics of European sequestrate Lactarioid Russulaceae with spiny spore ornamentation. Belg J Bot 136:145-153

Pegler DN (1982) Agaricoid and boletoid fungi (Basidiomycota) from Malawi and Zambia. Kew Bull 37:254-271

Pegler DN, Young TWK (1979) The Gasteroid Russulales. Trans Br Mycol Soc 72:353-388
Peter M, Büchler U, Ayer F, Egli S (2001) Ectomycorrhizas and molecular phylogeny of the hypogeous russuloid fungus Arcangeliella borziana. Mycol Res 105:1231-1238

Pierotti A (2015) Nomenclatural novelties. Index Fungorum 254:1

Reddell P, Spain AV, Hopkins M (1997) Dispersal of spores of mycorrhizal fungi in scats of native mammals in tropical forests of northeastern Australia. Biotropica 29:184-192

Ronquist F, Huelsenbeck JP (2005) MrBayes. Version 3.1.2. Bayesian analysis of phylogeny. GNU General Public License

Schickmann S, Urban A, Kräutler K, Nopp-Mayr U, Hackländer K (2012) The interrelationship of mycophagous small mammals and ectomycorrhizal fungi in primeval, disturbed and managed Central European mountainous forests. Oecologia 170:395-409

Smith SE, Read DJ (2008) Mycorrhizal symbiosis, 3rd edn. Academic Press, New York

Smith ME, Amses KR, Elliott TF, Obase K, Aime MC, Henkel TW (2015) New sequestrate fungi from Guyana: Jimtrappea guyanensis gen. sp. nov., Castellanea pakaraimophila gen. sp. nov., and Costatisporus cyanescens gen. sp. nov. (Boletaceae, Boletales). IMA Fungus 6:297-317

Sosef MSM (1996) Begonias and African rain forest refuges: general aspects and recent progress. In: van der Maesen LJG, van der Burg XM, van Medenbach JM (eds) The biodiversity of African plants. Kluwer Academic Publishers, Dordrecht, pp 602-611

Stadler M, Sterner O (1998) Production of bioactive secondary metabolites in the fruit bodies of macrofungi as a response to injury. Phytochemistry 49:1013-1019

Stamatakis A (2006) RAxML-VI-HPC: Maximum likelihood-based phylogenetic analyses with thousands of taxa and mixed models. Bioinformatics 22:2688-2690

Stamatakis A, Hoover P, Rougemont J (2008) A rapid bootstrap algorithm for the RAxML Web servers. Syst Biol 57:758-771

Sterner O (1995) Toxic terpenoids from higher fungi and their possible role in chemical defence systems. Cryptogam Mycol 16:47-57

Stubbe D, Verbeken A (2012) Lactarius subg. Plinthogalus: the European taxa and American varieties of L. lignyotus re-evaluated. Mycologia 104:1490-1501

Thiers HD (1984) The secotioid syndrome. Mycologia 76:1-8

Trappe JM (1988) Lessons from alpine fungi. Mycologia 80:1-10

Trappe JM, Cázares E (1990) Evolución, ecolgía y micofagia en los bongos hipogeos. Rev Mex Micol 6:33-40

Trappe JM, Claridge AW (2005) Hypogeous fungi: evolution of reproductive and dispersal strategies through interactions with animals and mycorrhizal plants. In: Dighton J, White JF, Oudemans P (eds) The fungal community, its organization and role in the ecosystem, 3rd edn. CRC Press, Boca Raton, pp 613-623

Van de Putte K, De Kesel A, Nuytinck J, Verbeken A (2009) A new Lactarius species from Togo with an isolated phylogenetic position. Cryptogam Mycol 30:39-44

Van Rooij P, De Kesel A, Verbeken A (2003) Studies in tropical African Lactarius species (Russulales, Basidiomycota) 11. Records from Benin. Nova Hedwigia 77:221-251

Verbeken A (2000) Studies in tropical African Lactarius species 8. A synopsis of the subgenus Plinthogali. Persoonia 17:377-406

Verbeken A, Buyck B (2002) Diversity and ecology of tropical ectomycorrhizal fungi in Africa. In: Watling R, Frankland JC, Ainsworth AM, Isaac S, Robinson CH (eds) Tropical mycology, vol 1, Macromycetes. CABI Publishing, Wallingford, pp $11-24$

Verbeken A, Walleyn R (2003) Una checklist dei funghi ipogei e secozioidi dell'Africa tropicale. Boll Gruppo Micol G Bresadola 46:87-96

Verbeken A, Walleyn R (2010) Fungus flora of tropical Africa Volume 2: Monograph of Lactarius in tropical Africa. National Botanical Garden of Belgium, Meise 
Verbeken A, Stubbe D, Nuytinck J (2008) Two new Lactarius species from Cameroon. Cyryptogam Mycol 29:137-143

Verbeken A, Stubbe D, van de Putte K, Eberhardt U, Nuytinck J (2014) Tales of the unexpected: angiocarpous representatives of the Russulaceae in tropical South East Asia. Persoonia 32: $13-24$

Vilgalys R, Hester M (1990) Rapid genetic identification and mapping of enzymatically amplified DNA from several Cryptococcus species. J Bacteriol 172:4238-4246
White TJ, Bruns T, Lee S, Taylor J (1990) Amplification and direct sequencing of fungal ribosomal RNA genes for phylogenetics. In: Innis MA, Gelfand DH, Sninsky JJ, White TJ (eds) PCR protocols: a guide to methods and applications. Academic Press, New York, pp 322-514

Wilson AW, Binder M, Hibbett DS (2011) Effects of gasteroid fruiting body morphology on diversification rates in three independent clades of fungi estimated using binary state speciation and extinction analysis. Evolution 65:1305-1322 